\title{
Viewpoint: The ecological value of shrub Islands on disturbed sagebrush rangelands
}

\author{
WILLIAM S. LONGLAND AND SHERYL L. BATEMAN
}

Authors are Ecologist, USDA, Agricultural Research Service, 920 Valley Road, University of Nevada, Reno, Nev. 89512; and Graduate Research Assistant, Department of Biology, University of Nevada, Reno, Nev. 89557.

\begin{abstract}
Undisturbed plant communities dominated by shrubs or trees are often left isolated within landscapes otherwise devoid of woody vegetation following large-scale disturbances such as wildfires. We discuss potential ecological benefits associated with these terrestrial vegetation "islands", giving special attention to islands in disturbed shrub systems dominated by big sagebrush (Artemisia tridentata Nutt.). Shrub habitat islands provide important refugia for plant and animal species that are associates of shrubs-from those that generally require shrub cover to those that have evolved obligate symbioses with a particular shrub species. Even if islands are not able to support breeding populations, they may provide essential temporary habitat for maintaining a plant or animal metapopulation or for dispersing animals. Habitat islands are likely to enhance local biological diversity of plants and animals, because they harbor species that are lacking in disturbed areas, and because abrupt structural changes from disturbed to undisturbed vegetation provide a habitat mosaic that facilitates high levels of species turnover. A previous study confirmed that small mammal species richness in sagebrush islands is intermediate to the high species richness in undisturbed sagebrush "mainlands" and the low richness associated with burned sagebrush habitats. In re-analyzing some of the data from the latter study, we found that small mammal richness in sagebrush islands increases with time since the surrounding habitat burned. Finally, habitat islands provide more evenly dispersed seed sources for re-establishment of decimated vegetation within disturbed areas, and they may harbor animal species that provide seed dispersal services. Thus, they should accelerate vegetation recovery after disturbance. Managers, fire crews, and others who may influence how disturbance patterns affect habitat heterogeneity should be aware of these ecological benefits of habitat islands.
\end{abstract}

Key Words: Artemisia tridentata Nutt., biological diversity, disturbance, Island Biogeography Theory, succession, terrestrial habitat islands

An alarmingly high proportion of arid western rangelands has been and continues to be converted to weedy monocultures as a result of disturbances that devastate native plant communities. The specific disturbance that has caused this floristic conversion

Authors wish to thank Sanjay Pyare, James Young, and three anonymous reviewers for commenting on the manuscript. This study is a contribution of the USDA, ARS, Exotic and Invasive Weed Research Unit, Reno, Nev.

Manuscript accepted 4 Mar. 2002.

\section{Resumen}

Comunidades vegetales sin disturbio dominadas por arbustos y árboles a menudo se quedan aisladas dentro de los paisajes desprovistos de vegetación leñosa después de ser sujetos a disturbios de gran escala como fuegos naturales. Discutimos los beneficios ecológicos potenciales asociados con esta "islas" terrestres de vegetación, poniendo especial atención a las islas en los sistemas arbustivos disturbados dominados por "Big sagebrush" (Artemisia tridentata Nutt.). Las islas de arbustos se proveen un refugio importante para especies de plantas y animales que están asociadas a los arbustos, desde aquellas que generalmente requieren de una cobertura de arbustos hasta aquellas que han evolucionado simbiosis obligadas con especies arbustivas particulares. Aun si las islas no son capaces de soportar poblaciones en reproducción ellas pueden proveer un hábitat temporal esencial para mantener una población de plantas o animales o para animales dispersantes. Los hábitats de las islas probablemente aumentarán la diversidad biológica de plantas y animales porque ellas refugian especies de las que carecen las áreas distrubadas y porque los cambios estructurales abruptos de una vegetación disturbada a una sin disturbio proveen un mosaico de hábitats que facilitan altos niveles de movimiento de especies. Un estudio previo confirmo que la riqueza de especies de pequeños mamíferos en las islas de "Sagebrush" es intermedia entre la alta riqueza de especies de las áreas sin disturbio y la baja riqueza asociada con los hábitats de "Sagebrush" quemados. Al reanalizar los datos del último estudio encontramos que la riqueza de pequeños mamíferos en las islas de "Sagebrush" aumenta con el tiempo a partir de los hábitats quemados que las rodean. Finalmente, los hábitats de las islas proveen fuentes de semilla con una dispersión mas uniforme para el reestablecimiento de la vegetación diezmada dentro de las áreas disturbadas y ellas también pueden refugiar especies animales que pueden dispersar la semilla. Así, ellos deben acelerar la recuperación de la vegetación después de un disturbio. Manejadores, cuadrillas de bomberos y otros quienes pueden influir en como los patrones de disturbio afectan la heterogeneidad de hábitats debe estar alerta de estos beneficios ecológicos de las islas de hábitat.

on the most extensive spatial scale is undoubtedly wildfire. Dense understories of non-indigenous, herbaceous weeds among native arid shrub communities have permitted fire to become commonplace in contemporary desert or semi-desert environments, where it was historically infrequent or even virtually absent (Billings 1990, Longland and Young 1995). Although the scale of catastrophic fires can denude the vast majority of an entire landscape 
of native vegetation, patches or "islands" of vegetation are often left isolated within the burned matrix due to natural or humanmade firebreaks, changes in wind direction while a fire burns, or other fortuitous causes (Fig. 1). We believe that such islands of unburned native vegetation embedded within an extensive disturbance have potentially great ecological value, and we discuss those values here. Although we focus on fire as a disturbance agent and on shrub habitat islands dominated by big sagebrush (Artemisia tridentata Nutt.), the benefits of such islands are applicable to other agents of disturbance and perhaps to islands of native herbaceous vegetation, as well.

\section{Habitat Islands as Refuges}

There are several species that are obligate associates of the shrub species that dominate undisturbed sagebrush rangelands. These include understory plant species that utilize shrubs as nurse plants, species that are parasitic on shrubs, herbivores on shrubs, and animal species that require the habitat structure provided by shrubs.

Insect herbivores are often highly specialized on particular plant species, including sagebrush (Christiansen et al. 1989, Wiens et al. 1991). Various species of moths (Hsiao 1986, Strenge and Zack 2001) and beetles (Pringle 1960), for example, are known to impact sagebrush, sometimes causing significant mortality. Any such phytophagous species that feeds specifically on sagebrush will obviously be doomed locally wherever sagebrush has been removed by disturbance. Such specialization is less common and usually less extreme among terrestrial vertebrates than in insects, but it does still occur. Sage grouse (Centrocercus urophasianus) and sagebrush voles (Lagurus curtatus), for example, require sagebrush in their diets, and would quickly perish where sagebrush has been removed by fire (cf., Nelle et al. 2000). Refugia provided by sagebrush islands could be very important to such species. This has particular practical significance in the case of sage grouse, a species that may be granted threatened status in the near future. Some herbivores that are more generalized, such as mule deer (Odocoileus hemionus), frequently include certain subspecies or varieties of sagebrush in their diets (Wambolt 2001, Welch and McArthur 1986), and thus would also be expected to be negatively impacted by sagebrush removal.

There are also many animal species with niche requirements that include some

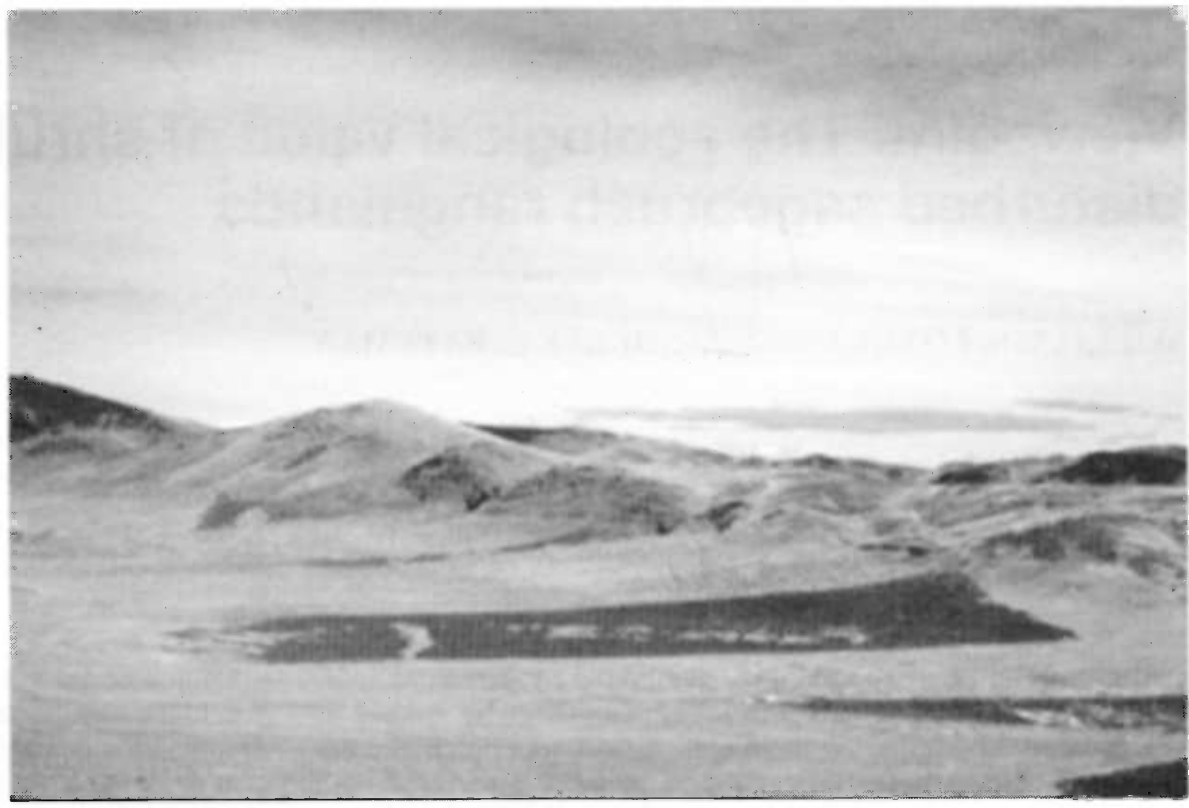

Fig. 1. Large ( $>37$ ha) sagebrush island isolated within a burned landscape near Pyramid Lake, Nev.

degree of habitat complexity, such as that provided by shrub cover. One such species, the pygmy rabbit (Sylvilagus idahoensis), is an obligate associate of sagebrush habitats (Weiss and Verts 1984), and, like the sage grouse, may be given threatened status soon. There are many other examples of small vertebrates that routinely avoid disturbed shrub communities, not because of specialization on sagebrush or some other plant species that is lacking after the disturbance, but because they would be at greater risk of predation due to increased conspicuousness where shrub cover is absent (Longland and Price 1991). These examples illustrate that, in addition to the shrub species that are directly impacted by disturbance, many closely associated species may also persist only within shrub mainland and island habitats following a large-scale disturbance.

Shrub habitat islands provide benefits to dispersing animals as well as residents within the islands. For any shrub-associated species with limited dispersal ability, shrub islands provide "stepping stones" by acting as temporary refuges to facilitate dispersal. Shrub islands may be useful in this regard even when they are too small to retain a breeding population. Similarly, habitat islands can provide essential temporary habitat for transient animals or for the maintenance of a metapopulation, a group of spatially disjunct subpopulations that are interlinked and maintained by occasional dispersal among the subpopulations. For example, certain small mammal species concentrate within sagebrush islands in high densities following fires, and the islands may therefore serve an important function in the persistence of a metapopulation of these species (Bateman 1999). For such species, sagebrush islands can not only maintain metapopulation structure by facilitating recolonization of extinct subpopulations through dispersal; these habitat islands may also serve to reduce local extinction probability, which appears to be relatively more important to metapopulation persistence than an increase in the probability of recolonization (Etienne and Heesterbeek 2001).

\section{Biological Diversity}

Island Biogeography Theory (IBT) is a well developed set of ideas that generate predictions concerning how physical attributes of islands should affect the diversity of species occurring on those islands. The theory reasons that the number of species that are able to successfully colonize an island from a mainland source is positively related to the size of the island, because more species can potentially coexist in a larger area, and is negatively related to the distance of the island from the mainland, because successful dispersal is less likely as distance increases. Island Biogeography Theory, as conceived by MacArthur and Wilson (1967), was intended for application to true oceanic islands, but its concepts were soon applied to the insularization of terrestrial environments, such as forested mountains surrounded by 
desert valleys (Brown 1971). We might expect these areas to represent "biological islands" to the species that are unique to such environments. Island Biogeography Theory may thus provide a useful framework for considering effects of shrub insularization on biological diversity.

One assumption of IBT almost certain to be true of shrub islands isolated by disturbance is that the species occurring in the islands are a subset of those that occur in undisturbed mainland plant communities. Habitat islands may contain the majority of the mainland species, but except for very large islands, they are likely to at least lack uncommon mainland plant species. And, while they may lack certain species that could potentially exist there, these unburned shrub islands certainly harbor species of woody shrubs that are lacking in surrounding burned areas. Like unburned mainland habitats, unburned islands also generally include (albeit in lower densities) the same native herbaceous plants and the same introduced weeds that quickly establish in and dominate the burned areas. By contrast to unburned vegetation associations, early successional vegetation within burned areas is usually composed of just a small subset of the local plant species pool and often approaches a monoculture.

It is clear, then, that for some time during early post-fire succession unburned shrub islands harbor both more plant species and consequently greater floristic genetic diversity than does the surrounding disturbed area. Such measures of diversity within a relatively small patch are often referred to as $\alpha$-diversity, whereas $\beta$ - and $\gamma$-diversity describe, respectively, the degree of species turnover among different patches in an area and the distinctness of patches across a landscape (Longland and Young 1995). Because entire plant taxa represented in unburned areas are absent from surrounding burns, species turnover between burned and unburned patches is dramatic, and the distinctness of burned versus unburned patches across a landscape is apparent. Thus, unburned vegetation islands enhance floristic $\beta$ - and $\gamma$-diversity at these larger spatial scales, as well as $\alpha$-diversity within the islands themselves.

In theory, animal biodiversity should also be greater in unburned plant communities than in the more uniform habitats provided by early successional, post-fire vegetation, and there is some empirical evidence that this is so. First, in comparative studies of small mammal species diversity in burned and adjacent unburned sagebrush habitats, species richness and evenness tended to be greater in the unburned, intact shrub communities (Longland 1995, Halford 1981). Second, in an extensive study comparing small mammal communities in burned areas, sagebrush islands within the burns, and in adjacent, continuous sagebrush communities, small mammal species richness typically was greatest in continuous sagebrush, lowest in the burned areas, and intermediate in the islands (Bateman 1999). Furthermore, such beneficial effects of habitat islands may extend to higher trophic levels in a "bottom-up" fashion; by providing refugia for prey species, islands could favor enhanced local diversity of predator species as well (Hixon and Beets 1993).

Another assumption of IBT that is likely to hold true in the context of terrestrial islands isolated by large-scale disturbances, is that island size should be positively related to the number of species inhabiting islands. First, chance inclusions of rare plant or animal species are simply more likely to occur within large islands than smaller islands. Also, larger islands offer more opportunities for heterogeneity in soil types, exposure, topography, and other landscape features that are likely to promote plant species diversity. The greater diversity of plants and physical features in larger islands should also translate into greater animal species diversity. Moreover, larger islands are more likely to include larger animal species, because their home range requirements may exceed the amount of habitat offered by many small islands.

The utility of another assumption of IBT - that the distance an island is isolated from mainland should be inversely related to species diversity harbored by the island-is less clear for terrestrial habitat islands than the assumption concerning island size. When a disturbance, such as fire, leaves behind an isolated island of habitat, there is no reason why the diversity of species contained within the island should be influenced by the distance that the island is left isolated from undisturbed (i.e., mainland) habitat. A distantly isolated island is likely to contain as many species after a fire as an island that is very close to the edge of the burned area. In classical IBT, it is the long-term processes of colonization and extinction of species on islands that leads to the expectation that greater isolation yields lower species diversity. The extinction rate of species is expected to be independent of isolation distance, while colonization is more likely on near than far islands. For terrestrial islands, however, isolation from their mainland species sources is not as difficult to overcome as the isolation of true oceanic islands. Many animal species, especially those with generalized habitat affinities, may be uninhibited from crossing large disturbances to reach habitat islands. Furthermore, the degree of isolation decreases over time for a terrestrial island as the disturbed area that isolates it undergoes succession and becomes more similar to the island and mainland habitats. Thus, the effect of isolation distance in habitat islands may be much greater on a shortlived species, especially one with poor dispersal ability, such as some flightless insects, small mammals, or annual plants, than on longer-lived species, such as woody shrubs. For long-lived taxa, the disturbed habitat surrounding an insularized population may undergo succession rapidly enough that the population is no longer effectively isolated by the time mortality within the island proceeds far enough to cause a risk of local extinction.

If one considers isolation of habitat islands in terms of effects of time and succession, IBT may offer relatively more insight into the value of these islands than it does through the usual considerations of isolation by distance. As an illustration, we reanalyzed Bateman's (1999) data on small mammal species richness in 23 sagebrush islands created by fire versus paired sagebrush "mainlands". Small mammal species richness was reduced in 19 of the islands compared with local species pools; only 4 islands contained all possible species. The mean age (i.e., time since burning) of the latter 4 islands was approximately double that of islands with reduced species numbers (16.0 vs. 8.1 years, respectively), a significant difference based on the 1-tailed expectation of lower species richness resulting from greater isolation (less time for succession, and therefore less similar vegetation between burned and unburned areas; Fig. 2a; 1-tailed $t=2.01 ;$ d.f. $=21, \mathrm{P}=0.029$ ). Relaxing the requirement of all species being sampled within the islands, we considered only those 10 sites in Bateman's data with $\leq 5$ small mammal species. At 4 of these sites where $\geq 80 \%$ of the local small mammal species occurred in sagebrush islands, mean time since the burn which isolated the islands was, again, significantly greater ( 16.8 years) than at the 6 sites where $<60 \%$ of species were retained in the island habitats $(9.2$ years; Fig. 2b; 1-tailed $t=2.78$, d.f. $=8, \mathrm{P}<$ 0.012 ). 

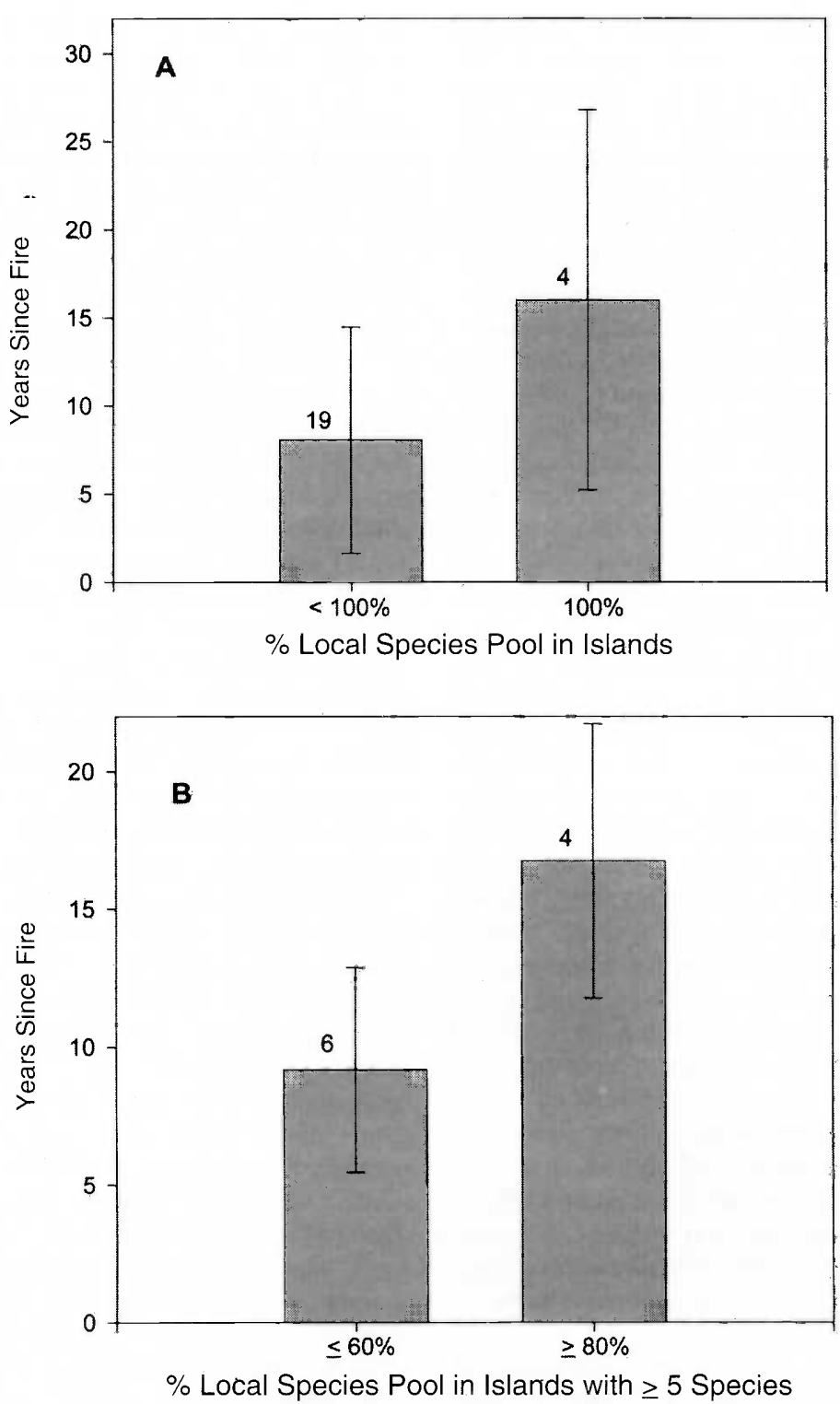

Fig. 2. Effect of time (years) since sagebrush habitat insularization by fire on percentages of local small mammal species pools occurring in habitat islands. A) All habitat islands sampled included-contrasts mean age of islands $( \pm 1$ SD) where $100 \%$ of small mammal species in local species pool occur in sagebrush islands versus islands with $<100 \%$ of species. B) Only includes habitat islands with $\geq \mathbf{5}$ small mammal species- contrasts mean age of islands $( \pm 1 \mathrm{SD})$ with $\geq 80 \%$ of species pool versus those with $\leq 60 \%$ of species. Numbers above bars are sample sizes of islands included in analyses. Data are from Bateman (1999).

It could be argued that habitat islands lose ecological value with time, because as succession proceeds, burned areas become more similar to the unburned shrub island and mainland areas they separate, effectively reducing isolation. While there is certainly some validity to this argument, Bateman (1999) still found more species in both islands and mainlands than in burns, and this pattern held up in old as well as recently burned sites.

From the above reasoning, if one judges the value of terrestrial islands on the basis models. For example, traditional IBT assumes that islands are inhabited by colonization (MacArthur and Wilson 1967), whereas in Bateman's (1999) sagebrush islands inhabitation can occur through survival of residual populations within the unburned islands. This is obviously the case for the plant populations occurring in these islands immediately following isolation by fire, but may also explain the presence of certain animal species. Moreover, most previous applications of IBT to terrestrial habitat islands (e.g., Brown 1971) involve habitats that have been insularized for sufficiently long time periods to permit repeated episodes of extinction and colonization to occur. By contrast, in the sagebrush system, plant succession may restore shrubs to the burned areas rapidly enough to make effects of extinction and colonization within isolated habitat islands negligible even for those species that cannot readily disperse across burns. Regardless of these considerations, though, Bateman's (1999) data suggest that at least some predictions of IBT are applicable to sagebrush habitat islands. Furthermore, terrestrial islands of any size or degree of isolation can provide essential habitat for certain species across a fragmented landscape, and they can have important effects on succession within a surrounding disturbed area.

\section{Successional Processes}

Although we have already discussed potential effects of post-fire succession on habitat islands, we have not touched on the how the presence of islands may, in turn, affect successional processes. Most woody shrub species that occur in sagebrush environments must reestablish in disturbed areas from seeds; vegetative sprouting from roots following fire is relatively uncommon (Billings 1990). Thus, for successional recovery of a disturbance to proceed, a supply of viable seeds is necessary, and these seeds must find their way to appropriate sites for germination and seedling establishment. A large-scale disturbance that has islands of native vegetation embedded in it provides a more evenly distributed seed source for successional recovery across the disturbed landscape than simply relying on dispersal of seeds from edges of the disturbance (i.e., from the shrub mainland). This, alone, is likely to speed the recovery process for seeds dispersed by either biotic or abiotic agents. It is, perhaps, even more likely to enhance recovery for plant species whose 
seeds are dispersed by small mammals, which is probably a relatively common phenomenon in arid western shrub environments (Vander Wall 1990). The shrub islands provide not only a ready source of seeds for these animals to harvest, consume, and disperse, but also a refuge for various species that can act as effective seed dispersers. Deer mice (Peromyscus maniculatus), and various chipmunks (Tamias spp.), ground squirrels (Spermophilus spp. and Ammospermophilus spp.), and pocket mice (Perognathus spp. and Chaetodipus spp.), for example, all tend to have strong preferences for shrub-covered over disturbed areas with reduced shrub densities (such as burns), and all are potentially important seed dispersers (Bateman 1999, Halford 1981, Longland 1995). By contrast, kangaroo rats (Dipodomys spp.) also disperse the seeds of various desert plants, but they generally increase in abundance in disturbed areas, preferring them to heavy shrub cover. Even in this case, though, shrub islands can provide seed sources that allow these animals to disperse seeds of native plant species into the disturbed habitat matrix.

\section{Management Implications}

What practical applications can be gleaned from the above concepts? First and foremost is our central message - that native vegetation islands embedded within otherwise disturbed environments have high potential ecological and conservation value. Thus, these islands should be preserved whenever possible following disturbance. In fact, it may sometimes be possible or even advisable to manage for the maintenance or establishment of shrub islands during the planning of prescribed fire or even during the effort to control a wildfire. For example, if an advancing line of fire is too large and/or moving too rapidly to allow establishment of a fire break along the entire advancing front, it may still be possible to use smaller fire breaks to facilitate the creation of unburned shrub islands within the larger burned matrix. We suggest that agency handbooks should address these issues explicitly in cases where policies regarding habitat islands are currently either lacking or ambiguous.

If the agent of vegetation disturbance is under more direct human control than disturbance by fire, such as mechanical shrub removal, it may be possible to intentionally leave established shrub islands or to restore them later as part of the rehabilita- tion effort. Even in cases where large fires cleanly denude a landscape of shrubs, restoration of native shrub islands within the burn may prove to be an effective means of accelerating natural successional recovery. It is certainly less costly than active revegetation of an entire burned environment, and the result of successional expansion of vegetation islands is likely to yield a closer match to the preburn plant community. The latter approach is being attempted in the Buttermilk Winter Range Restoration Project at the eastern base of the Sierra Nevada Mountains in Round Valley, Calif. In 1995, 2,000 ha of critical mule deer winter range was cleanly consumed by fire in this area, but insufficient funds and concern about the introduction of non-native plant germplasm prohibited attempts to actively revegetate the entire area. Instead, a large number of 10- x 10$\mathrm{m}$ plots have been planted with antelope bitterbrush (Purshia tridentata [Pursh] DC) seedlings grown from local seed stocks, and the plots have been made selectively accessible to mule deer and to seed-eating rodents. This project will thus simultaneously evaluate the utility of vegetation islands for restoration and the effects of 2 potential keystone animal taxa on plant succession.

A more general message extending beyond the issue of habitat islands is that theoretical constructs in ecology, conservation biology, or management are more than complications or annoyances that must be overcome during our years as students. They are heuristic tools that can often instruct real life problems. Predictions of Island Biogeography Theory have been tested for a variety of terrestrial habitat island situations, and applied to the optimal design or location of wildlife reserves. Most such examples involve forested habitats isolated by surrounding non-forested lands, but there is no reason why the same principles should not be applicable to arid rangelands. There can be useful, even valuable, empirical lessons hidden in sometimes seemingly esoteric theories.

\section{Literature Cited}

Bateman, S.L. 1999. Effects of habitat fragmentation in Great Basin sagebrush-bunchgrass communities for small mammals and arthropods. M.S Thesis, Univ. of Nevada, Reno, Nev.. 72 pp.

Billings, W.D. 1990. Bromus tectorum, a biotic cause of ecosystem impoverishment in the Great Basin. p. 210-222. In: G.M. Woodwell (ed.). The Earth in Transition: Patterns and Processes of Biotic Impoverishment. Cambridge University Press, New York, NY.
Brown, J.H. 1971. Mammals on mountaintops: nonequilibrium insular biogeography. Amer. Natur. 105:467-478.

Christiansen, T.A., J.A. Lockwood, and J. Powell. 1989. Arthropod community dynamics in undisturbed and intensively managed mountain brush habitats. Great Basin Natur. 49:570-586.

Etienne, R.S. and J.A.P. Heesterbeek. Rules of thumb for conservation of metapopulations based on a stochastic winking-patch model. Amer. Natur. 158:389-407.

Halford, D.K. 1981. Repopulation and food habits of Peromyscus maniculatus on a burned sagebrush desert in southeastern Idaho. NW. Sci. 55:44-49.

Hixon, M.A. and J.P. Beets. 1993. Predation, prey refuges, and the structure of coral reef fish assemblages. Ecol. Monogr. 63:77-101.

Hsiao, T.H. 1986. Biology and demography of the sagebrush defoliator and its impacts on big sagebrush. p. 191-198. In: E.D. McArthur and B.L. Welch (comps.). Proc. Symp. on the Biology of Artemisia and Chrysothamnus. USDA Forest Serv., Intermountain Res. Sta., Gen. Tech. Rep. INT-GTR-200, Ogden, Ut.

Longland, W.S. 1995. Desert rodents in disturbed shrub communities and their effects on plant recruitment. p. 209-215. In: B.A. Roundy and E.D. McArthur (eds.). Proc. Symp. on Wildland Shrub and Arid Land Restoration. USDA Forest Serv., Intermountain Res. Sta., Gen. Tech. Rep. INT-GTR-315, Ogden, Ut.

Longland, W.S. and M.V. Price. 1991. Direct observations of owls and heteromyid rodents: can predation risk explain microhabitat use? Ecol. 72:2261-2273.

Longland, W.S. and J.A. Young. 1995. Landscape diversity in the western Great Basin. p. 880-891. In: N. West (ed.). Biodiversity on Rangelands. Natural Resources and Environmental Issues Series, Utah State Univ, Logan, Ut.

MacArthur, R.H. and E.O. Wilson. 1967. The theory of island biogeography. Princeton University Press, Princeton, N.J.

Nelle, P.J., K.P. Reese, and J.W. Connelly. 2000. Long-term effects of fire on sage grouse habitat. J. Range Manage. 53:586-591.

Pringle, W.L. 1960. The effect of a leaf feeding beetle on big sagebrush in British Columbia. J. Range Manage. 13:139-142.

Strenge, D.L. and R.S. Zack. 2001. Observations on the life history of the sagebrush sheep moth, Hemileuca hera hera (Lepidoptera: Saturniidae). NW Sci. 75:118-121.

Vander Wall, S.B. 1990. Food hoarding in animals. University of Chicago Press. Chicago, Ill.

Wambolt, C.L. 2001. Mule deer preference among five sagebrush (Artemisia L.) taxa. Western North Amer. Natur. 61:490-494.

Welch, B.L. and E.D. McArthur. 1986. Wintering mule deer preference for 21 accessions of big sagebrush. Great Basin Natur. 46:281-286.

Weiss, N.T. and B.J. Verts. 1984. Habitat and distribution of pygmy rabbits (Sylvilagus idahoensis) in Oregon. Great Basin Natur. 44:563-571.

Wiens, J.A., R.G. Cates, J.T. Rotenberry, N. Cobb, B. Van Horne, and R.A. Redak. 1991. Arthropod dynamics on sagebrush (Artemisia tridentata): effects of plant chemistry and avian predation. Ecol. Monogr. 61:299-321. 